\title{
Genotoxicity and tumor inducing potential of roadside soil samples exposed to heavy traffic emissions at A mritsar (Punjab), India
}

\author{
Raj want K aur ${ }^{1}$, Yogesh B. Pakade ${ }^{2}$ and J atinder K aur K atnoria ${ }^{1 *}$ \\ ${ }^{1}$ Department of Botanical and Environmental Sciences, Guru Nanak Dev University, Amritsar, (Punjab), INDIA \\ ${ }^{2}$ Hill Area Tea Science Division, CSIR-Institute of Himalayan Bioresources and Technology, Palampur (Himachal Pradesh), \\ INDIA \\ *Corresponding author. E-mail: jkat08@yahoo.com
}

Received: J uly 24, 2013; Revised received: August 26, 2013; Accepted: September 1, 2013

Abstract: Noxious gases released from vehicles adversely affect the microbial population of the roadside soil as well as exerts influence on plant growth and development. Considering the increasing vehicular pollution in Amritsar, a holy city of Punjab (India) and their serious consequences in terms of health problems, the present study was planned to estimate genotoxic and tumor inducing potentials of soil samples from Golden temple (GT) and Putlighar Chowk (PG) by employing Allium cepa root chromosomal aberration assay (AIRCAA) and Potato disc tumor assay (PDTA), respectively. The genotoxic potential in terms of percent aberrant cells in A. cepa was found to be $29.24 \%$ (GT) and $29.24 \%$ (PG) during in situ treatment and $39.00 \%$ (GT) and $39.48 \%$ (PG) during root dip treatment. The average number of tumors was found to be 14.4 in PG sample, followed by 13.0 in GT sample. Both samples have shown high content of lead viz., 39.81 (GT) and 56.48 (PG) during physicochemical analysis of the samples.

Keywords: Automobiles, Genotoxic, Heavy metals, Physico-chemical analysis

\section{INTRODUCTION}

Transportation is one of the important components of any country's economics growth, yet it has many negative impacts on environment. Vehicles play a significant role in aggravating the pollution of different ecosystems (Plakhotnik et al., 2005; Abechi et al., 2010). The vehicular emissions are the major cause for soil pollution because the air pollutants released into the atmosphere ultimately settle on the ground surface. Therefore, roadside soil contains huge concentrations of pollutants that may deteriorate environmental quality and have toxicological effects on human health. The different types of pollutants released from vehicles are heavy metals, polycyclic aromatic hydrocarbons, oxides of nitrogen and sulphur (Jaradat and Momani, 1999; Imperato et al., 2003; Akbar et al., 2006; Abechi et al., 2010; Evagelopoulos et al., 2010). The pollutants either get accumulated in the surface soil or are transported to the deeper layers of soil leading to its physicochemical alterations (Mbah and Anikwe, 2010). Moreover, the contaminants released from vehicular emissions enter the biological system and cause health hazards to plants, animals and human (Ozaki et al., 2004; Makokha et al., 2008; Sujetoviene and Griauslyte, 2008; Joshi et al., 2010).

To explore the consequences of various pollutants, different bioassays have been recommended (Conder et al., 2001; Sujetoviene and Griauslyte, 2008; Katnoria et al., 2011). A number of studies have shown the presence of DNA damaging pollutants in different samples using a number of bioassays viz., Allium cepa root chromosomal aberration assay (Rank and Nielsen 1998; Chakraborty et al., 2009; Katnoria et al., 2011; Abu and Mba, 2011), Allium sativum root chromosomal aberration assay (Yi and Meng, 2003; Liu et al., 2009; Saxena et al., 2010), Tadescantia stamen hair mutation assay (Arutyunyan, et al., 1999; Marciulioniene et al., 2004), Vicia faba chromosomal aberration/micronuclei assay (Misik and Mmicieta, 2002; Kontek et al., 2007; Gulfishan et al., 2010) and Potato disc tumor assay (Coker et al., 2003).

However, to have the exact magnitude of the pollution of environment, the physico-chemical analysis has its own importance. Some scientists have, therefore, studied the soil ecosystem by analysis of various physico-chemical properties like $\mathrm{pH}$, alkalinity, soil texture, water holding capacity, bulk density, nitrates, phosphates, potassium, calcium, sodium, magnesium, chlorides and lead (Garcia et al., 2001; Garg, 2002; Kulkarni and aggarwal, 2003; Aseri and Tarafdar, 2006; Glori et al., 2008 and Katnoria et al., 2011). Considering the increased exposure of people to traffic emissions in Amritsar, Punjab (India), the present study was planned to estimate the genotoxic and tumor inducing potential 
of surface soil samples exposed to vehicular emissions.

\section{MATERIALS AND METHODS}

Collection of soil samples: Soil samples were collected from two different road junctions of Amritsar viz., Golden temple (GT) and Putlighar (PG) by scraping of surface soil. The soil samples were brought to laboratory and dried for $72 \mathrm{~h}$ (Cabrera and Rodriguez, 1999). The samples were used to analyze the physico-chemical characteristics, genotoxic and tumor inducing potential. A nalysis of soil samples: The physico-chemical parameters viz., $\mathrm{pH}$, alkalinity, bulk density, water holding capacity, soil texture, chlorides, calcium, magnesium, nitrates, phosphates, potassium, sodium and lead of soil samples were analyzed by using standard protocols (Trivedy et al., 1987; Akbar et al., 2006 and Katnoria et al., 2011). The estimation of lead was carried out at Institute of Himayan Bioresourse Technology (IHBT), Palampur using Atomic absorption spectrophotometer with graphite furnace.

Estimation of genotoxic potential: The genotoxic potential of soil samples was estimated by using A. cepa root chromosomal aberration assay. A. cepa root chromosomal aberration assay performed in two modes viz., in situ treatment and root dip treatment to evaluate the genotoxic potential of soil samples During root dip treatment, peeled onion bulbs were kept for root germination in distilled water for 24-36 h. The emerged roots $(0.5-1.0 \mathrm{~cm})$ were treated with different concentrations $(25 \%, 50 \%, 75 \%$ and $100 \%)$ of soil extracts $(1: 2, \mathrm{w} / \mathrm{v}$; soil : distilled water) for $3 \mathrm{~h}$. During in situ treatment, the peeled onion bulbs were directly placed on soil contained in small pots and were allowed to root for 24-36 h. then the root tips were washed thoroughly with distille water, cut and fixed in farmer's fluid (3: 1: : ethanol : glacial acetic acid). Slides were prepared by squashing in aceto-orcein stain and scanned under microscope for scoring different types of aberrations. Distilled water and acid washed sand were treated as negative control during root dip and in situ treatment, respectively.

Estimation of tumor inducing potential: The tumor inducing potential of soil samples was estimated using potato disc tumor assay (Cooker et al., 2003). The grown gall bacteria Agrobacterium tumifaciens strain MTCC (Microbial Type Culture Collection and Gene Bank) No. 431 was purchased from Institute of Microbial Technology (IMTECH), Chandigarh and was used for the experiment. The Potato disc tumor assay was performed in two modes viz., with culture and without culture and two types of soil extracts i.e. aqueous and Dimethyl sulfoxide (DMSO) extract were used. The lab area was sterilized using 20\% Bleach solution. Fresh Russet potatoes purchased from local grocery store were washed thoroughly under running tap water for 2-3 min and were peeled off. The potatoes were cut with the help of cork borer $(1 \mathrm{~cm})$ and discs of $0.5 \mathrm{~cm}$ height prepared. The discs were sterilized with $10 \%$ Bleach solution. The potato discs were imbedded in agar plates (Petridish) up to $2 / 3 \mathrm{rd}$ of the height. $400 \mu \mathrm{l}$ of soil extract and $400 \mu \mathrm{l}$ of culture of $A$. tumefaciens were mixed in a vial and $50 \mu \mathrm{l}$ of the mixture was put on each disc. In another set, $50 \mu 1$ of only soil extracts was poured on to the discs. $50 \mu \mathrm{l}$ of only culture was used as positive control while $50 \mu$ l of distilled water and $50 \mu 1$ of DMSO were used as respective negative controls. Petri plates were covered, sealed with parafilm and incubated in B.O.D. incubator for 21 days to induce tumors. After inoculation period, potato discs were analyzed for scoring number of induced tumors using stereomicroscope at $25 \mathrm{X}$ magnification after staining with Lugol's Solution (5\% KI + $\left.5 \% \mathrm{I}_{2}\right)$.

\section{RESULTS AND DISCUSSION}

Diverse contaminants breakthrough the soil ecosystem either naturally from soil parent material, volcanic eruptions, forest fires etc. or arthropogenically by use of pesticides and activities such as mining, smelting, transportation, refining etc. Apart from this, heavy metals enter the soil through wear and tear of tyres, construction of railway and road lines (Haal et al., 2008). This is the reason that most of the surface roadside soils are reported to be polluted with heavy metals. The polluted soils are of concern due to the fact that under supersaturated conditions through rainfalls or surface water runoff, the pollutants percolate through the soil profile and contaminate the ground water. Moreover, the movement of vehicles can re-suspend the pollutants by causing the highly turbulent conditions which expose the people to these pollutants via inhalation of dust particles.

In the present study, lead content was found to be 39.81 $\mathrm{mg} / \mathrm{Kg}$ in GT and $56.48 \mathrm{mg} / \mathrm{Kg}$ in PG sites which were under the exposure to heavy metal transportation. Although there are no permissible limits defined for soil ecosystem, yet, Aggarwal (2009) has given the typical concentration of $\mathrm{Pb}$ in lithosphere as $10 \mu \mathrm{g} / \mathrm{g}$ while its range as $2-200 \mu \mathrm{g} / \mathrm{g}$. The concentration of $\mathrm{Pb}$ in both the samples were found to be higher than the typical concentration of $\mathrm{Pb}$ as given by Aggarwal (2009). Similar studies have been conducted worldwide and many reports support the fact of increased lead contents along the roadside soils (Jaradat and Momani, 1999; Onder et al., 2007; Abechi et al., 2010). The other physico-chemical parameters were also analyzed and results are shown in Table 1. Both samples have alkaline $\mathrm{pH}$ while bulk density was found to be slightly higher i.e. 1.92 (GT) and 1.834 (PG) than the normal bulk density $(1.3-1.6)$ of the agriculture soil samples while the other parameters were 
Table 1. Physico-chemical characteristics of roadside soil samples of Amritsar, Punjab (India).

\begin{tabular}{|c|c|c|c|}
\hline \multicolumn{2}{|l|}{ Parameters } & Golden temple (GT) & Putiighar (PG) \\
\hline \multicolumn{2}{|l|}{$\mathrm{pH}$} & $7.66 \pm 0.01$ & $8.43 \pm 0.01$ \\
\hline \multicolumn{2}{|c|}{ Alkalinity (meq/100g) } & $0.40 \pm 0.05$ & $0.560 \pm 0.03$ \\
\hline \multicolumn{2}{|c|}{ Bulk density (g/cc) } & $1.92 \pm 0.00$ & $1.834 \pm 0.00$ \\
\hline \multicolumn{2}{|c|}{ Water holding capacity (\%) } & $24.11 \pm 0.12$ & $37.91 \pm 0.34$ \\
\hline \multirow[t]{3}{*}{ Soil texture } & Sand $(\%)$ & $43.07 \pm 1.00$ & $41.49 \pm 0.19$ \\
\hline & Silt $(\%)$ & $29.50 \pm 0.04$ & $35.99 \pm 0.64$ \\
\hline & Clay $(\%)$ & $26.89 \pm 0.86$ & $22.33 \pm 0.75$ \\
\hline \multicolumn{2}{|c|}{ Chlorides (mg/g) } & $0.02 \pm 0.00$ & $0.02 \pm 0.00$ \\
\hline \multicolumn{2}{|c|}{ Calcium (mg/g) } & $4.81 \pm 0.46$ & $2.14 \pm 0.26$ \\
\hline \multicolumn{2}{|c|}{ Magnesium (mg/g) } & $11.19 \pm 1.66$ & $27.20 \pm 0.40$ \\
\hline \multicolumn{2}{|c|}{ Nitrates $(\mathrm{mg} / \mathrm{g})$} & $0.22 \pm 0.00$ & $0.01 \pm 0.00$ \\
\hline \multicolumn{2}{|c|}{ Phosphates (mg/g) } & $0.03 \pm 0.00$ & $0.09 \pm 0.00$ \\
\hline \multicolumn{2}{|c|}{ Potassium $(\mathrm{mg} / \mathrm{g})$} & $8.10 \pm 0.06$ & $11.20 \pm 0.00$ \\
\hline \multicolumn{2}{|c|}{ Sodium (mg/g) } & $33.66 \pm 0.21$ & $29.50 \pm 0.23$ \\
\hline \multicolumn{2}{|c|}{ Lead (mg/Kg) } & $39.81 \pm 0.00$ & $56.48 \pm 0.00$ \\
\hline
\end{tabular}

within the range as earlier reported by Warhate et al. (2006). The study was further carried out to explore the genotoxic and tumor inducing potential of both soil samples using bioassays. It was observed that both soil samples induced genotoxicity in A. cepa root tips cells and showed the tumor inducing potential during Potato disc tumor assay. During genotoxicity assay, the percentage of different types of physiological (C-mitosis, abnormal anaphase, abnormal metaphase, delayed anaphase, laggad/s, vagrant/s, stickiness) as well as clastogenic (chromosomal breaks, chromatin bridge and ring chromosomes) aberrations were observed in root tip cells of $A$. cepa exposed to both soil samples (Fig. 3). The Golden temple sample showed $23.85 \%$ physiological aberrations while $5.39 \%$ clastogenic aberrations during in situ treatment. The aberrant cell in GT was found to be $39.00 \%$. The frequency of physiological and clastogenic aberrations at different concentrations viz., $25 \%, 50 \%, 75 \%$ and $100 \%$ were $18.68 \%, 27.48 \%, 33.40 \%$ and $34.08 \%$ and $2.85 \%$, $2.53 \%, 4.09 \%$ and $4.92 \%$, respectively. In PG sample, the percentage of various physiological aberrations was found to be $25.63 \%$ while the percentage of clastogenic aberrations was $5.46 \%$ during in situ treatment. $25.04 \%$, $27.53 \%, 33.18 \%$ and $39.48 \%$ of total aberrant cells were found at $25 \%, 50 \%, 75 \%$ and $100 \%$, respectively during root dip treatment in PG sample. Many authors consider the plant bioassays as first alerts/biological indicators to explore the harmful consequences of environmental complex mixtures (Sujetoviene and Griauslyte, 2008; Leme et al., 2008; Hoshina and Marin-Morales, 2009). The clastogenic damages in terms of tumor induction were further observed in the second bioassay i.e. Potato Disc Tumor assay. The tumor inducing potential of soil samples is shown in Fig.4. When the potato disc assay was performed without $A$. tumifaciens culture, the aqueous golden temple extract (AGT), the maximum numbers of tumors (12.0) were found at $100 \%$, while minimum (1.4) were found at $25 \%$. In the DMSO golden temple extract (DGT), the number of tumors were ranged from $1.6(25 \%)$ to $3.6(100 \%)$. The mean number of tumors in aqueous extract Putlighar (APG) varied from 1.0 (25\%) to $4.8(100 \%)$ while in DMSO extract Putlighar (DPG), the number of tumors varied from $1.6(25 \%)$ to $3.2(100 \%)$. When the potato disc assay was performed with Agrobacterium tumifaciens culture, the aqueous extract with culture $(\mathrm{AGT}+\mathrm{C})$, the mean number of tumors varied from $5.4(25 \%)$ to $13.0(100 \%)$ whereas in DMSO extract with culture (DMSO+C), the mean number of tumors varied from $3.4(25 \%)$ to $5.4(100 \%)$. The mean number of tumors at $25 \%, 50 \%, 75 \%$ and $100 \%$ of aqueous extract Putlighar with culture (APG+C) were found to be 4.6, 5.4, 6.8 and 14.4 , respectively while mean number of tumors at $25 \%, 50 \%, 75 \%$ and $100 \%$ of DMSO Putlighar extract (DMSO+C) were 4.4, 5.4, 6.6 and 6.8, respectively.

Although there are many studies related to use of this bioassay as antitumor activities of various plant extracts (Hadizadeh et al., 2007; Silva et al., 2012; Karakas et al., 2012), very few studies reported its use in direct clastogenic effect. During infection of a plant with A. tumefaciens, a tumor producing plasmid (Ti) is incorporated with the plants chromosomal DNA which activates if phenols are released (Coker et al., 2003). Ti plasmid causes the plants cell to multiply rapidly without going through apoptosis results in tumor formation that histologically is similar to human and animal cancers (Agrios, 1997). 


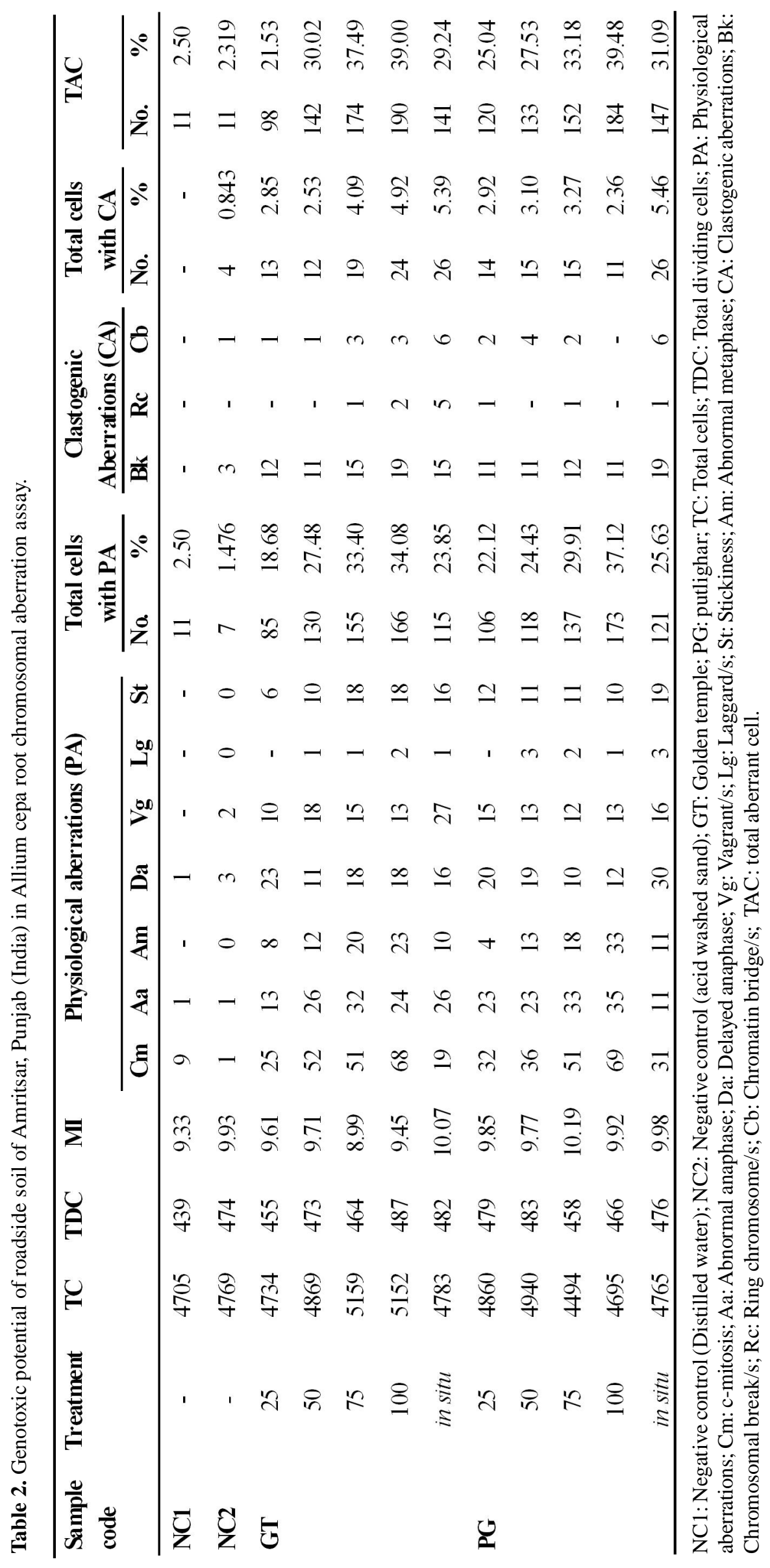




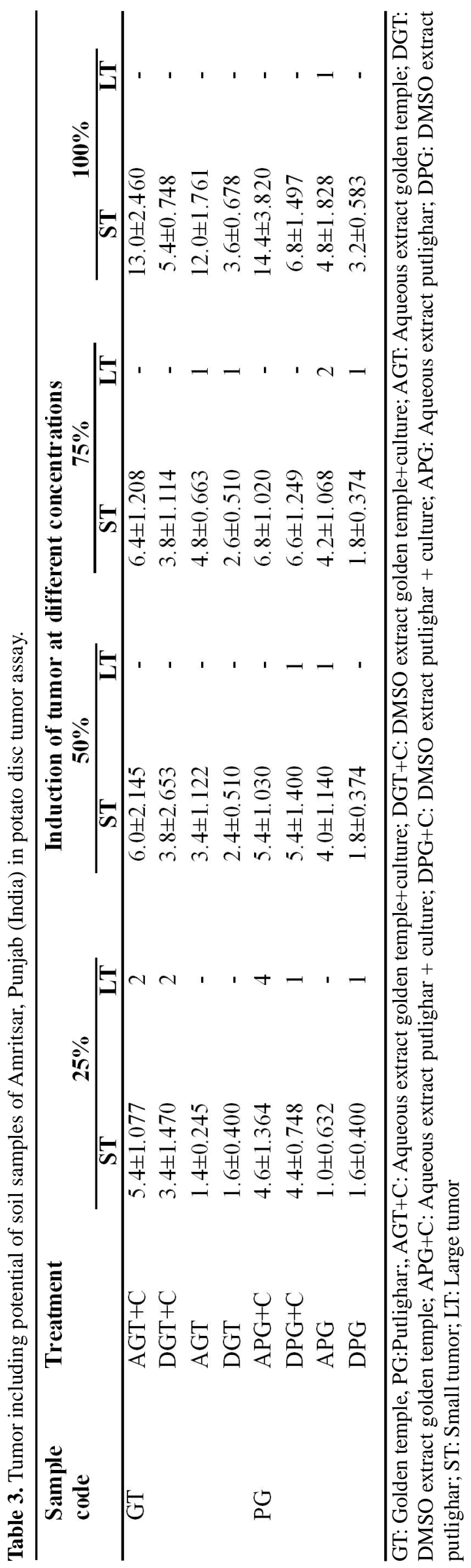

\section{Conclusion}

Average increase of concentration of lead in roadside soil was directly correlated with increase of vehicular pollution in the city. Lead is widely documented to be one of the major metal pollutants released from vehicles in the roadside environments and has to induce potential genotoxicity/carcinogenicity. There was an increase $\mathrm{Pb}$ concentration in roadside soil samples of Amritsar city and also showed genotoxicity/carcinogenicity in both the bioassays used.

\section{ACKNOWLEDGEMENT}

Thanks are due to Dr. P. S. Ahuja, Director, Institute of Himalayan Bioresources and Technology (IHBT), Palampur, Himachal Pradesh (India) for providing necessary facilities for estimation of lead.

\section{REFERENCES}

Abechi, E.S., Okunola, O.J., Zubairu, S.M.J., Usman, A.A. and Apen, E. (2010). Evalution of heavy metals in roadside soils of major streets in Jos metropolis, Nigeria. J ournal of Environmental and Chemical Ecotoxicology, 2: 98-102.

Abu, N.E. and Mba, K.C. (2011). Mutagenecity testing of phamarceutical effluents on Allium cepa root tip meristems.J ournal of Toxicology and Environmental Health Science, 3:44-51.

Agrios, GN. (1997) Plant diseases caused by prokaryotes: bacteria and mollicutes. Plant Physiology. Academic Press, San Diego.

Aggarwal, S.K. (2009). Heavy metal pollution. A.P.H Publishing Corporation. New Dehli.

Akbar, K.F., Hale, W.H.G., Headley, A.D. and Athar, M. (2006). Heavy metals contamination of roadside soils of northern England. Soil and Water Research, 1: 158-163.

Arutyunyan, R.M., Pogosyan, V.S., Simonyan, E.H., Atoyants, A.L. and Djigardjian, E.M. (1999). In situ monitoring of the ambient air around the chloroprene rubber industrial plant using the Tradescantia-stamen-hair mutation assay. Mutation Research/Fundamental Molecular Mechanism Mutatation,426: 117-120.

Aseri, G.K. and Tarafdar, J.C. (2006). Fluorescein diacetate: a potential biological indicator for arid soils. Arid Land Research M anagement, 20: 87-99.

Cabrera, G.L. and Rodriguez, D.M. (1999). Genotoxicity of leachates from a landfill using three bioassays. Mutation Research, 426: 207-210.

Chakraborty, R., Mukherjee, A.K. and Mukherjee, A. (2009). Evaluation of genotoxicity of coal fly ash in Allium cepa root cells combining comet assay with the Allium test. Environment M onitoring and Assessment, 153: 351-357.

Coker, P.S., Radecke, J., Guy, C. and Comper, N.D. (2003). Potato disc tumor inducing assay: A multiple mode of drug action assay. Phytomedicine, 10: 133-138.

Conder, J.M., Lanno, R.P. and Basta, N.T. (2001). Assessment of metal availability in smelter soil using earthworms and chemical extractions. J ournal of Envi ronment Q uality, 30: 1231-1237.

Evagelopoulos, V., Albanis, T.A., Asvesta, A. and Zoras, S. (2010). Polycyclic aromatic hydrocarbons (PAHs) in fine and coarse particles. Global NEST J ournal, 12: 63-70. 
Garcia, M.J.M., Moreno-Grau, S., Gracia, J.J.M., Moreno, J., Bayo, J., Perez, J.J.G. and Moreno-claved, J. (2001). Distribution of metals lead, cadmium, copper and zinc in topsoil of Cartagena, Spain. Water Air and Soil Pollution, 131: 329-347.

Garg, S.S. (2002). Seasonal variation in physico-chemical parameters of soil of Nagar Panchayat, Chitrakoot. Indian J ournal of Environmental Protection, 22: 1105-1112.

Ghosh, S.P., Maiti, S.K. and Singh, G. (2009). Heavy metals contamination in roadside soil and vegetation: A review. International J ournal of Environmental Pollution, 29:334-341.

Glori, R.L., Miren, O., Ibone, A., Iker, M. and Carlos, G. (2008). Relationship between vegetation diversity and soil functional diversity in native mixed-oak forests. Soil Biology and Biochemistry, 40: 49-60.

Gulfishan, M., Khan, A.H. and Bhat, T.A. (2010). Studies on cytotoxicity induced by DES and SA in Vicia faba var. major. Turk J ournal of Botany, 34: 31-37.

Haal, M.L., Surje, P. and Rouk, H. (2008). Traffic as a source of pollution. Estonian J ournal of Engineering, 14: 65-82.

Hadizadeh, F., Moradi, A., Naghibi, G., Vojdani, M., Behravan, J. and Ramezani, M. (2007). Synthesis and antitumor activity of substituted succinamides using a potato disc tumor induction assay. International J ournal of Biomedical Science, 3: 60-64.

Hoshina, M.M. and Marin-Morales, M.A. (2009). Micronucleus and chromosome aberrations induced in onion (Allium cepa) by a petroleum refinery effluent and by river water that receives this effluent. Ecotoxicology and Environmental Safety, 72: 2090-2095.

Imperato, M., Adamo, P., Naimo, D., Arienzo, M., Stanzione, D. and Violente, P. (2003). Spatial distribution of heavy metals in urban soils in Naples city (Italy). Environmental Pollution, 124: 247-256.

Jaradat, Q.M. and Momani, K.A. (1999). Contamination of roadside soil, plants and air with heavy metals in Jordan: A comparative study. Turk J ournal of Chemistry, 23: 209-220.

Joshi, S.R., Kumar, R., Saikia, P., Bhagobaty, R.K. and Thokchom, S. (2010). Impact of roadside pollution on microbial activities in Sub-Tropical forests soil of North East India. Research J ournal of E nvir onmental Science, 4: 280-287.

Karakas, F.P., Yildirim, A. and Turker, A. (2012). Biological screening of various medicinal plant extracts for antibacterial and antitumor activities. Turk J ournal Biology, 36: 641-652.

Katnoria, J.K., Arora, S., Bhardwaj, R. and Nagpal, A. (2011). Evaluation of genotoxic potential of industrial waste contaminated soil extracts of Amitsar, India. J ournal of Environmental Biology, 32: 363-367.

Kontek, R., Osieck, R. and Kontek, B. (2007). Clastogenic and mitodepressive effects of the insecticide dichlorvos on root meristems of Vicia faba. J ournal of Applied G enetics, 48: 359-361.

Kulkarni, N.P. and Aggarwal, Y.K. (2003). Physico-chemical characterization of the topsoil of a hospital. Indian J ournal of Environmental Protection, 23: 503-507.

Leme, D.M., Angelis, D.F. and Marin-Morales, M.A. (2008). Action mechanisms of petroleum hydrocarbons present in waters impacted by an oil spill on the genetic material of Allium cepa root cells. Aquatic Toxicology, 8: 214-219.
Liu, D., Jiang, W., Meng, Q., Zou, J., Gu, J. and Zeng, M. (2009). Cytogenetical and ultrastructural effects of copper on root meristem cells of Allium sativum L. Biocell, 33: 25-32.

Makokha, A.O., Mghweno, L.R., Magoha, H.S., Nakajugo, A. and Wekesa, J.M. (2008). Environmental lead pollution and contamination in food around Lake Victoria, Kisumu, Kenya. African J ournal of E nvironmental Science and Technology, 2: 342-348.

Marciulioniene, D., Montvydiene, D., Kiponas, D., Luksiene, B. and Butkus, D. (2004). Toxicity to Tradescantia of technogenic radionuclides and their mixture with heavy metals. Environmental Toxicology, 19: 346-350.

Mbah, C.N. and Anikwe, M.A.N. (2010). Variation in heavy metal contents on roadside soils along a major express way in south east Nigeria. New York Science J ournal, 3: 103-107.

Misik, M. and Mmicieta, K. (2002). Tradescantia micronucleus and Vicia chromosome ana-telophase assays in monitoring of genotoxicity of urban soil. Water Air and Soil Pollution, 141: 181-187.

Onder, S., Dursun, S., Gezgin, S. and Demirbas, A. (2007) Determination of Heavy Metal Pollution in Grass and Soil of City Centre Green Areas (Konya, Turkey). Polish J ournal of Environmental Studies, 16: 145-154.

Ozaki, H., Watanabe, I. and Kuno, K. (2004). As, Sb and Hg distribution and pollution sources in the roadside soil and dust around Kamikochi, Chubu Sangaku National Park Japan. G eochemical J ournal, 38: 473-484.

Plakhotnik, V.N., Onyshchenko, J.V. and Yaryshkina, L.A. (2005). The environmental impacts of railway transportationin the Ukraine. Transportion Research Part D, 10: 263-368.

Rank, J. and Nielsen, M.H. (1998). Allium cepa anaphase telophase root tip chromosome aberration assay on $\mathrm{N}$ mathyle-N-nitrosourea, maleic hydrazide, sodium azide and ethyl methanesulfonate. M utation Research, 390: 121-127.

Saxena, P.N., Gupta, S.K. and Murthy, R.C. (2010). Carbofuran induced cytogenetic effects in root meristem cells of Allium cepa and Allium sativum: A spectroscopic approach for chromosome damage. Pesticide Biochemistry and Physiology, 96: 93-100.

Silva, R.M.G., Rodrigues, D.T.M., Augustos, F.S., Valadares, F., Neto, P.O., Santos, L. and Silva, L.P. (2012). Antitumor and cytotoxic activity of Kielmeyera coriacea mart. Zucc. and Pyrostegia venusta (ker-gawl.) Miers extracts. J ournal of M edical Plants Research, 6: 4142-4148.

Sujetoviene, G. and Griauslyte, L. (2008). Toxicity assessment of roadside soil using wild oat (Avena sativa L.) and cress (Lepidium sativum L.) morphometric and biochemical parameters. Environmental Research and Engineering Management, 4: 29-35.

Trivedy, R.K., Goel, P.K. and Trisal, C.L. (1987). Aquatic Ecosystem In: Practical methods in ecology and environmental sciences. Enviro Media Publications. Karad, India, Pp 57-113.

Warhate, S.R., Yenkie, M.K.N., Chaudhari, M.D. and Pokale, W.K. (2006). Impacts of mining activities on water and soil. J ournal of Environmental Science and Engineering. 48: 81-90.

Yi, H. and Meng, Z. (2003). Genotoxicity of hydrated sulfur dioxide on root tips of Allium sativum and Vicia faba. M utation Research, 537: 109-114. 